\title{
INSTRUMENTOS MUSICAIS DOS ÍNDIOS AIKEWÁRA
}

GILMAR MATTA DA SILVA ${ }^{1}$

UFPA

RESUMO: $O$ artigo tem o objetivo de apresentar aspectos referentes aos instrumentos musicais dos Aikewára que habitam a Área Indígena Sororó, no sudeste do Estado do Pará. A metodologia utilizada envolveu pesquisa bibliográfica, a participação e observação do cotidiano da sociedade aikewára e entrevistas qualitativas com os especialistas aikewára. Com base nos resultados de análise, verificou-se que o conhecimento dos respectivos sujeitos do estudo, acionado pelas lembranças do tempo antigo, valorizam a aprendizagem em torno dos instrumentos musicais via a interação dos índios com Musenái, tomando tal experiência como modelo de socialização intergeracional.

PALAVRAS-CHAVE: Aikewára; instrumentos musicais; socialização.

ABSTRACT: The article aims to present aspects related to musical instruments of the Aikewara people, who inhabit the Sororó Indigenous Lante, Southeastern Pará State. The methodology consists in bibliographical research, observation and participation in the daily routine of the Aikewára and interviews with Aikewára experts. Based on the results of analysis it was found that their knowledge is triggered by the old time memories. They value the act of learning about musical instruments through the interaction with Musenái, which makes this experience a model of intergenerational socialization.

KEYWORDS: Aikewára; musical instruments; socialization.

\section{Introdução}

Os Aikewára, também conhecidos como Suruí ou Suruí do Pará, são um povo do tronco Tupi, classificado no subconjunto da família TupiGuarani, que ocupa com outros povos indígenas a região do sudeste do

\footnotetext{
${ }^{1}$ Mestre em Antropologia Social pela Universidade Federal do Pará (UFPA), professor colaborador da mesma universidade e sócio efetivo da Associação Brasileira de Etnomusicologia (ABET). O texto se baseia em parte de minha dissertação de mestrado, Sapurahái de Karuára: mitos, instrumentos musicais e canto entre os Suruí Aikewára (2007). E-mail: gilmar.matta@gmail.com.
} 
Estado do Pará. A sociedade aikewára habita a Área Indígena Sororó, situada entre o Igarapé Gameleira (afluente do Araguaia) e o Grotão dos Caboclos, um dos formadores do Rio Sororó, afluente do Itacaiúna, tributário do Rio Tocantins (LARAIA, 1978). Na atualidade, a Área Indígena Sororó abrange parte das terras dos municípios de Marabá, São Domingos do Araguaia e São Geraldo do Araguaia, que no passado constituíam o território aikewára.

Os recursos naturais encontrados na fauna e na flora proporcionam a utilização das matérias-primas necessárias para a feitura dos instrumentos musicais, como, por exemplo, cascos (unhas) de porco-domato para a fabricação do sykã (chocalho em cacho), tabocas (taquara) para a fabricação das symyá (flautas), sementes de mungulú, penas de aves e cuité (cuia) para a feitura do wapusáz (maracá). Os Aikewára, assim como outras sociedades indígenas, ao produzirem os seus objetos, trabalham com outros aspectos cognitivos, além daqueles que incluem as matérias-primas, como "[...] os procedimentos mentais (perceptivos, lógicos e matemáticos) e sensíveis (relativos a estética e criatividade artística) [...]" (VIDAL e LOPES DA SILVA, 1995, p. 380). Tais aspectos são necessários para a sua produção e manuseio, mas ultrapassam essa dimensão.

Os instrumentos musicais, para além da função de auxiliar o canto, tornam-se sua própria extensão, revelam a produção de uma ordem simbólica entre as culturas indígenas, como, por exemplo, os instrumentos entre os Wauja envolvem concepções relacionadas ao gênero (MELLO, 1999). Entre os Kamayurá apresentam origens míticas (MENEZES BASTOS, 1978). E no caso dos Arará as flautas tnat-tanat, que executam temas melódicos para comunicar aos oto (espíritos "donos de bichos") que o ato de caça já foi realizado ou está em andamento (TEIXEIRA PINTO, 1997). Tais exemplos, que estão relacionados aos contextos específicos das sociedades indígenas mencionadas acima, permitem ao pesquisador interpretar o significado que eles representam para as sociedades ou grupos, para compreender a construção simbólica existente sobre esses objetos.

\footnotetext{
${ }^{2}$ É uma palavra que na língua aikewára significa maracá; entretanto, a palavra chocalho globular se refere ao instrumento musical - presente nas sociedades indígenas brasileiras - conhecido como maracá ou maraká, por ser visto entre os Tupinambás, a partir do registro dos viajantes (CAMEU, 1977). Para fins do artigo, considero wapusá como sinônimo de maracá e de chocalho globular.
} 
Neste artigo apresento os instrumentos musicais aikewára e o processo de aprendizagem em torno da elaboração destes objetos pelos

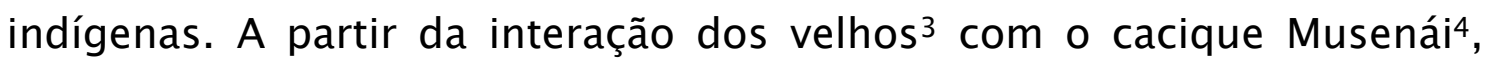
acionada pela memória dos referidos sujeitos, se revive reminiscências do tempo antigo e se destaca o saber (fazer) em torno de suas práticas culturais, tomando a experiência de interação como modelo de socialização intergeracional, para em seguida tecer considerações sobre o wapusá (maracá) e a symyápytáwa (trompete). A metodologia do trabalho envolveu a pesquisa de campo realizada entre os Aikewára na Área Indígena Sororó, sudeste do Estado do Pará, entre anos de 2005 a 2007. O estudo foi orientado pela abordagem interpretativista com auxílio das técnicas de observação participante, permitindo a vivência do cotidiano da aldeia, e entrevistas qualitativas com os experientes ${ }^{5}$ aikewára sobre ideias e práticas relacionadas aos instrumentos musicais. Inicialmente destaco a experiência de trabalho com os instrumentos musicais indígenas das coleções etnográficas da Reserva Técnica do Laboratório de Antropologia Arthur Napoleão Figueiredo (LAANF) da Universidade Federal do Pará (UFPA) para chegar na pesquisa com os instrumentos musicais aikewára.

\section{Das coleções etnográficas para os instrumentos musicais aikewára}

Os artefatos recolhidos em museus e reservas técnicas, que compõem as coleções etnográficas, são documentos materiais que, ao serem estudados como ferramenta de análise, possibilitam ao pesquisador obter a compreensão das expressões materiais e imateriais desenvolvidas pelas sociedades produtoras, a fim de entender os

\footnotetext{
${ }^{3}$ Para os Aikewára, "os velhos" não são unicamente as pessoas de mais idade, incluem também as pessoas experimentadas em termos dos saberes da sociedade aikewára e que os socializam para os demais. Para fins do artigo, considero "velho" como sinônimo de experiente e de especialista.

${ }^{4}$ Antigo cacique dos Aikewára que detinha o poder político e religioso. É considerado pelos experientes um grande líder, devido a suas ações mantendo o grupo afastado do contato com os não índios e pelos ensinamentos das práticas sociais.

${ }^{5}$ Pessoas que, dentro das práticas culturais dos Aikewára, destacam-se pelas habilidades que possuem em torno da construção dos instrumentos musicais, dos cantos, mitos e de outros elementos da cultura aikewára; sendo reconhecidos socialmente entre os demais membros da sociedade e indicados no assunto, saltando à condição de experientes por terem aprendido as práticas culturais com o antigo cacique Musenái, respeitado pela sua sabedoria e por dominar um amplo conhecimento das práticas indígenas. Durante a pesquisa trabalhei regularmente com sete experientes, sendo seis homens e uma mulher.
} 
significados atribuídos a essas peças, que apresentam um conteúdo simbólico de grande importância na vida das sociedades indígenas (RIBEIRO E VELTHEM, 1992). Sob o ponto de vista de estudos envolvendo a abordagem interpretativa e a etno-história, as coleções etnográficas ${ }^{6}$ Protásio Frikel (1965) e Eduardo Galvão e Protásio Frikel (1966), da Reserva Técnica do LAANF, da UFPA, foram contextualizadas, respectivamente, por Domingues-Lopes (2002) e Lacerda-Lima (2003). As autoras, adotando os procedimentos de análises acima, compreenderam os sentidos e significados atribuídos aos objetos que compõem as referidas coleções. Dentre esses objetos estão o maracá xikrín e a flauta juruna.

A partir do conhecimento dessas experiências de estudo, e relacionando meu interesse pela música e pela cultura material indígena, teve início o trabalho com as coleções 7 , tendo como foco de estudo os Instrumentos Musicais e de Sinalização da Reserva Técnica do LAANF, da UFPA, a partir da identificação desses objetos nos catálogos de Figueiredo (1981) e Domingues-Lopes et al. (2003), para saber em quais coleções se encontravam, a que sociedades indígenas pertenciam tais objetos, e de que tipo de instrumentos se tratava. Nas coleções Protásio Frikel (1965); Eduardo Galvão e Protásio Frikel (1966); Arthur Napoleão Figueiredo e Anaíza Vergolino e Silva (1969); e Arthur Napoleão Figueiredo (1972) verificou-se a existência de 31 instrumentos musicais e de sinalização, indicados e distribuídos entre oito sociedades indígenas (anambé, juruna,

\footnotetext{
${ }^{6}$ As coleções etnográficas que estão sob a guarda da Reserva Técnica do LAANF, da UFPA, foram organizadas por Arthur Napoleão Figueiredo, em 1981. O acervo é formado por coleções de sociedades indígenas, coleções interioranas e coleções afro-brasileiras. As peças que formam as 12 coleções das sociedades indígenas são provenientes do Estado do Pará e do Mato Grosso, e foram recolhidas por Protásio Frikel, Eduardo Galvão, Arthur Napolão Figueiredo e Anaíza Vergolino-Henry, no período de 1965 a 1972. Deve-se ressaltar que, entre as coleções indígenas, se encontram peças (araráw [adorno de cabeça], braçadeiras, instrumentos musicais) da sociedade aikewára que foram doadas por Mastop-Lima (2002) e Matta da Silva (2007), após a realização de suas pesquisas. As coleções indígenas começaram a ser trabalhadas a partir do projeto Coleções Etnográficas: testemunhos da educação, história e diversidade na Amazônia, coordenado pela Prof. ${ }^{a}$ Dr. ${ }^{a}$ Jane Felipe Beltrão (UFPA), tendo como resultado produções acadêmicas de Beltrão (2000 e 2003), Domingues-Lopes (2000), Domingues-Lopes e Beltrão (2003). Com relação aos estudos referentes às coleções afro-brasileiras encontram-se os trabalhos de Campelo (2007), Campelo e Albuquerque (2007) e Campos (2014 e 2015). O acervo constitui-se em um rico material de pesquisa que pode ser estudado por pesquisadores interessados pela cultura material, com o objetivo de analisar as coleções dentro de um amplo campo de estudo envolvendo cultura material, etnomusicologia, etno-história, tecnologias tradicionais, entre outros.

${ }^{7}$ Coleção pode ser [...] qualquer conjunto de objetos naturais ou artificiais, mantidos temporária ou definitivamente fora do circuito das actividades [sic] econômicas, sujeitos a uma proteção especial num local fechado preparado para esse fim, e exposto ao olhar do público (POMIAN, 1985, p. 53). Verbete Coleção.
} 
kamayurá, kuikuro, trumai, xikrín, tiriyó e xaruma), como flauta, maracá, bastão de ritmo e apito.

De posse dos dados, os instrumentos musicais foram classificados em dois grandes grupos (aerofones ${ }^{8}$ e idiofones ${ }^{9}$ ), mediante a sistematização proposta por Ribeiro $(1988)^{10}$. Depois procedi ao levantamento bibliográfico, com a finalidade de obter informações das referidas sociedades para compor a descrição das peças, e à produção de desenhos ${ }^{11}$, com o objetivo de se criar um registro gráfico das mesmas para mostrar seus detalhes, o que ajudou na descrição, evitando o excessivo manuseio das peças e, consequentemente, seu desgaste. $\mathrm{Na}$ medida em que entrava em contato com as peças, visualizando seus aspectos constitutivos, fui percebendo que tais objetos assumem ou assumiam funções específicas dentro do contexto cultural em que foram produzidos. Então, pensar sobre as peças no locus onde estavam encerradas se tornava o primeiro exercício de estranhamento, conforme propõe DaMatta (1978). Além disso, um novo encaminhamento do trabalho com os instrumentos musicais foi ocorrendo. Diante da diversidade das peças e das sociedades indígenas produtoras ficaria inviável conduzir uma proposta de trabalho envolvendo todas as coleções, ou mesmo realizar viagens a campo para se obter informações, devido à falta de recursos. A solução encontrada foi conduzir o estudo dos instrumentos musicais e da música junto a uma sociedade indígena, no caso os Aikewára, a partir do projeto Etnoconhecimento Suruí: a fauna no universo Aikewáral2. Com base nessa mudança de objeto de estudo, passo a descrever a experiência de contextualizar os instrumentos musicais entre os Aikewára.

\footnotetext{
${ }^{8} \mathrm{O}$ grupo dos instrumentos aerofones é caracterizado por [...] instrumentos de sopro que produzem som mediante a vibração do ar soprado no interior de um receptáculo como flautas e apitos, ou quando são postos a girar em torno de seu próprio eixo, como os zunidores (RIBEIRO, 1988, p. 195).

${ }^{9} \mathrm{O}$ grupo dos instrumentos idiofones é caracterizado como [...] instrumentos que soam mediante a vibração da própria matéria de que são feitos, como os bastões maciço de ritmo, chocalhos e tambores feitos a partir da carapaça de tartaruga são utilizados tanto para produzir som, quanto para marcar os passos em uma festa (RIBEIRO, 1988, p. 195).

${ }_{10}$ Deve-se ressaltar que Ribeiro baseou-se na sistemática dos instrumentos musicais formulada por Hornbostel e Sachs (1961) para organizar a categoria Instrumentos Musicais e de Sinalização presente em sua obra Dicionário do Artesanato Indígena.

${ }^{11}$ Sobre o detalhamento do processo de trabalho com os instrumentos musicais existentes nas coleções etnográficas da Reserva Técnica do LAANF, da UFPA, consultar Domingues-Lopes e Silva (2005).

${ }^{12}$ Projeto coordenado pela Prof. ${ }^{\text {a }}$ Ma. Luiza de Nazaré Mastop-Lima (UFPA) teve como objetivo realizar um mapeamento da fauna e os usos de seus elementos pelos Aikewára na confecção dos artefatos, destinados às atividades lúdicas e rituais.
} 
A sociedade aikewára é detentora de um conhecimento que abrange sua cultura material 13 e imaterial expresso na fabricação dos instrumentos musicais, cantos, pajelança, mitos, arcos, flechas, colares, araráw, danças, entre outros. Os conhecimentos são compartilhados e vivenciados entre os seus integrantes ao longo de sua vida. Mesmo considerando as influências advindas do contato com a sociedade regional e nacional, os Aikewára, ao fazer uso dos elementos referidos acima, se constituem numa sociedade que fomenta entre os jovens os ensinamentos herdados de seus ancestrais como forma de se autoafirmar enquanto grupo étnico ${ }^{14}$ diante do outro. De acordo com as informações obtidas entre seus membros, os conhecimentos sobre a cultura aikewára são repassados pelas pessoas mais experientes, dando continuidade às práticas da sociedade.

Então, são os experientes e a abrangência do conhecimento transmitido aos membros da sociedade aikewára que permitem o desenvolvimento de suas práticas e crenças, que, dentro de um contexto, revelam muito de si para os outros, como nos propõe Geertz (1998), quando problematiza a base que fundamenta $o$ entendimento antropológico em relação ao nativo. A postura do pesquisador requer sensibilidade e esforço no exercício da atividade de trabalho de campo, visando à aplicação do instrumental compatível com a realidade a ser analisada, interpretando o ponto de vista dos sujeitos acerca de suas práticas que envolvem os instrumentos musicais, a música e demais aspectos a ela relacionados na sociedade aikewára como forma de revelar sua visão de mundo.

No ensaio Do ponto de vista dos nativos: a natureza do entendimento antropológico, Geertz (1998) suscita uma discussão epistemológica em torno dos temas abordados no diário de Malinowski (1997), sobre como o antropólogo pode ser capaz de compreender as formas sociais referidas pelos nativos. O procedimento adotado para solucionar esta questão encontra-se no ir e vir constante entre as

\footnotetext{
${ }^{13}$ Cultura material pode ser definida como [...] a totalidade dos bens materiais que um povo possui para adornar e vestir-se, alimentar e abrigar-se, para poder lutar contra os inimigos e para traficar, para fazer música e ter divertimentos, em resumo, todos os dados concretos de uma cultura (BALDUS e WILLEMS, 1939, p. 73). Verbete Cultura material.

14 Grupo étnico [...] são categorias atributivas e identificadoras empregadas pelos próprios atores; conseqüentemente, têm como característica organizar as interações entre as pessoas (BARTH, 2000, p. 25).
} 
categorias expressas pelos nativos e as categorias empregadas pelos antropólogos, o que, dentro do princípio hermenêutico na análise interpretativa, permite ao antropólogo alcançar o entendimento das formas sociais alheias. Dessa forma é possível revelar as singularidades das culturas, mediante a capacidade descritiva e interpretativa da ciência antropológica em busca dos significados atribuídos às práticas sociais e visões de mundo dos seres humanos.

Geertz explicita as suas formulações em exemplos, levando em consideração a noção de pessoa e suas distinções em Bali, Marrocos e Java. Apresenta, por meio de representações formuladas pelos os indivíduos, como eles se se percebem. Tudo isso faz com que o autor alcance o entendimento de que a cultura é simbólica e partilhada pelos seres humanos, seja na sua forma teatralizada, filosófica ou ritualística. É nesse processo de interpretação que a noção de tradução - que consiste em "[...] mostrar a lógica das formas de expressão dos nativos, com a nossa fraseologia" (GEERTZ, 1998, p. 20) - ganha sentido, enquanto ferramenta metodológica para a Antropologia, mediante a experiência pessoal do pesquisador em contato com seus interlocutores.

As primeiras saídas pela aldeia foram marcadas pelos contatos que mantive com os Aikewára que conheci quando cheguei na Área Indígena Sororó: a família de Arihêra ${ }^{15}$, de Maria16, e no próprio espaço da casa onde estava alojado. O que me proporcionou, pela conversa estabelecida com os Aikewára, conhecer possíveis interlocutores sobre o assunto a ser abordado. Após esses contatos passei a transitar pelo espaço da aldeia e da floresta na companhia de Kaipí, um jovem aikewára que posteriormente me relatou ser neto do antigo pajé Awasaí. Além de Kaipí, contei com a ajuda de Mureirú17 indicando e me conduzindo até os velhos.

Para as conversas que mantive com os velhos, passei a me apoiar nas pessoas da família, que serviram de tradutores a fim de estabelecer o diálogo entre ambas as partes. Mas isso não resolveria o problema, pois

\footnotetext{
15 É uma experiente que se destaca na arte de narrar os mitos e de outras práticas aikewára que foram repassadas por sua mãe e também no contato que teve quando criança com Musenái.

${ }^{16}$ É uma experiente que, apesar de não ser de origem aikewára, chegou à aldeia ainda pequena e se incorporou à vida do grupo; posteriormente, casou com um aikewára. É reconhecida na arte da pintura corporal e na arte de manipular ervas, habilidades que adquiriu no contato outros experientes.

${ }^{17}$ Mureirú é agente de saúde no posto da aldeia e filha de Arihêra.
} 
sabia que nem sempre contaria com a ajuda dos familiares, seja pelo fato de não se encontrarem em casa no momento em que fosse conversar com os velhos, seja pelas atividades que desenvolvem mesmo quando se encontram em suas residências. Por isso me mantinha atento à conversa, observando como falavam e como me ouviam para poder perguntar, dava exemplos da sociedade a que pertenço procurando relacionar com os costumes da sociedade aikewára, na qual estão inseridos meus interlocutores. Utilizando esse procedimento, identifiquei os instrumentos musicais e obtive informações a seu respeito, bem como acompanhei o seu processo de fabricação. Nas casas dos experientes, entrei em contato com os instrumentos musicais que integram o universo sonoro aikewára.

Ao entrar no interior da casa de Mihó ${ }^{8}$, e estabelecendo diálogo com outros índios, tomei conhecimento da existência dos instrumentos musicais como o wapusá (maracá), o sykã (chocalho em cacho) e a symyá19 (flauta), que abrange cinco tipos diferenciados.

Nas andanças pela aldeia, se constatou que alguns instrumentos, como no caso o wapusá (maracá), apresentam semelhanças com os artefatos das coleções etnográficas da UFPA20. Em meio a isso, logo ocorreram surpresas, pois, quando estava na casa de Wariní21, depareime com a symyápytáwa (trompete) que acopla em seu tubo um cuité (cuia) fixado com cera de abelha. Na parte distal do tubo existe um bocal que propaga o ar para o interior do cuité, que funciona como uma caixa acústica que amplifica o som do instrumento, sendo ajudada com a presença de um defletor de cera de abelha. Além do referido instrumento musical, havia a symyápy (flauta transversa), que é fechada na extremidade distal, apresentando, 3 centímetros à frente, um orifício

\footnotetext{
${ }^{18}$ Experiente que é o pajé dos Aikewára. Apresenta habilidades na construção dos instrumentos musicais, na narração dos mitos, cantos e danças. Exerce papel central na condução dos procedimentos rituais no sapurahái (palavra que se refere às danças coletivas) de karuára (abrange a categoria de espíritos especiais). Uma definição mais completa sobre os termos sapurahái e karuára será fornecida posteriormente.

${ }^{19}$ Os nomes das flautas com as suas respectivas terminações são: symyá (flauta reta), symyápytáwa (trompete), symyápy (flauta transversa), symyápéw (flauta de pã).

${ }^{20}$ As peças da reserva técnica foram produzidas por membros de sociedades tupi, tupi-guarani e jê, entre outros.

${ }^{21}$ Wariní é um experiente que apresenta um amplo conhecimento sobre os mitos, instrumentos musicais e outras práticas dos Aikewára. Além disso, exerce papel ritual de upurahasuewa'é (o portador do cigarro) no sapurahái de karuára, que tem a função de defumar as mulheres durante a dança.
} 
labial de 1 centrímetro de diâmetro a conduzir o ar soprado pelo interior do tubo.

Figura 1: Instrumentos musicais aikewára.

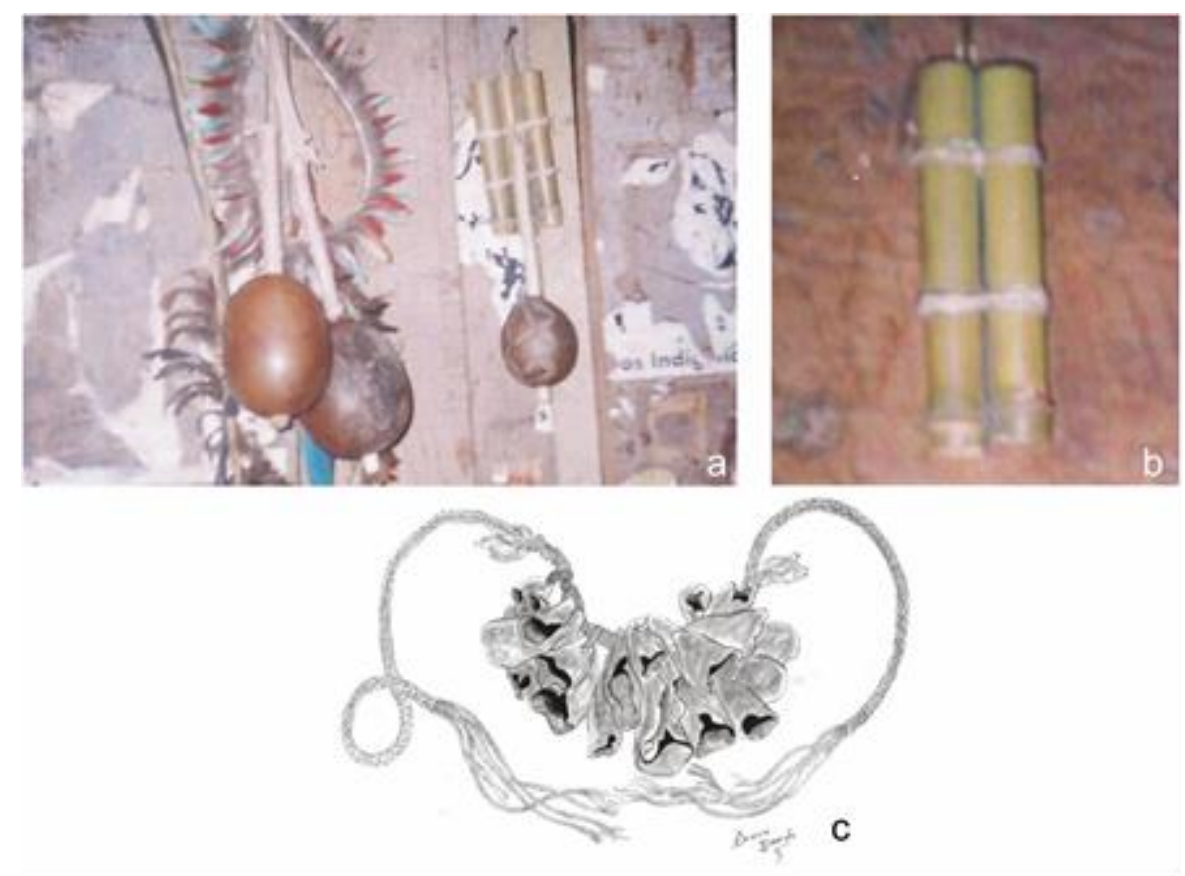

Fonte: (a) Wapusá (maracá) e symyápéw (flauta de pã) de três tubos. Autor: Matta da Silva, 21/07/2005. (b) Symyápéw de dois tubos. Autor: Matta da Silva, 21/07/2005. (c) Sykã . Autor: Lima, 26/07/2006.

Em outra ocasião, ao conhecer a casa tradicional, denominada na língua aikewára de ogg'ete (casa de verdade), ou - como também os índios chamam - "casa da cultura", constatei que funcionava como uma espécie de "museu"22. A ideia de se conceber um "museu" na aldeia tomando como locus a moradia tradicional ocorreu por meio da implantação de um projeto da Fundação Casa da Cultura de Marabá realizado pela Escola Municipal de Música Maestro Moisés Araújo em 2004, que visou coletar a música aikewára na Área Indígena Sororó. O projeto estimulou a construção da casa para guardar os objetos aikewára com a finalidade de ser manter viva a memória da sociedade, bem como

\footnotetext{
${ }^{22}$ Segundo Ribeiro e Velthem (1992), outros casos da experiência de museus em aldeias foram encontrados entre os índios Desana (maloca museu), entre os índios Tikuna (casa da cultura dos índios Tikuna) e entre os índios do Oiapoque com os museus etnográficos, entre outros. A experiência com a criação de museus mostra a consciência das sociedades indígenas em relação ao papel social dos museus "[...] enquanto lugares onde novos significados podem ser atribuídos aos movimentos de preservação cultural e de afirmação de identidades" (VELTHEM, 2012, p. 58).
} 
práticas e saberes acionados por meio de sua cultura material para as futuras gerações.

Figura 2: Indígena e instrumentos musicais aikewára.

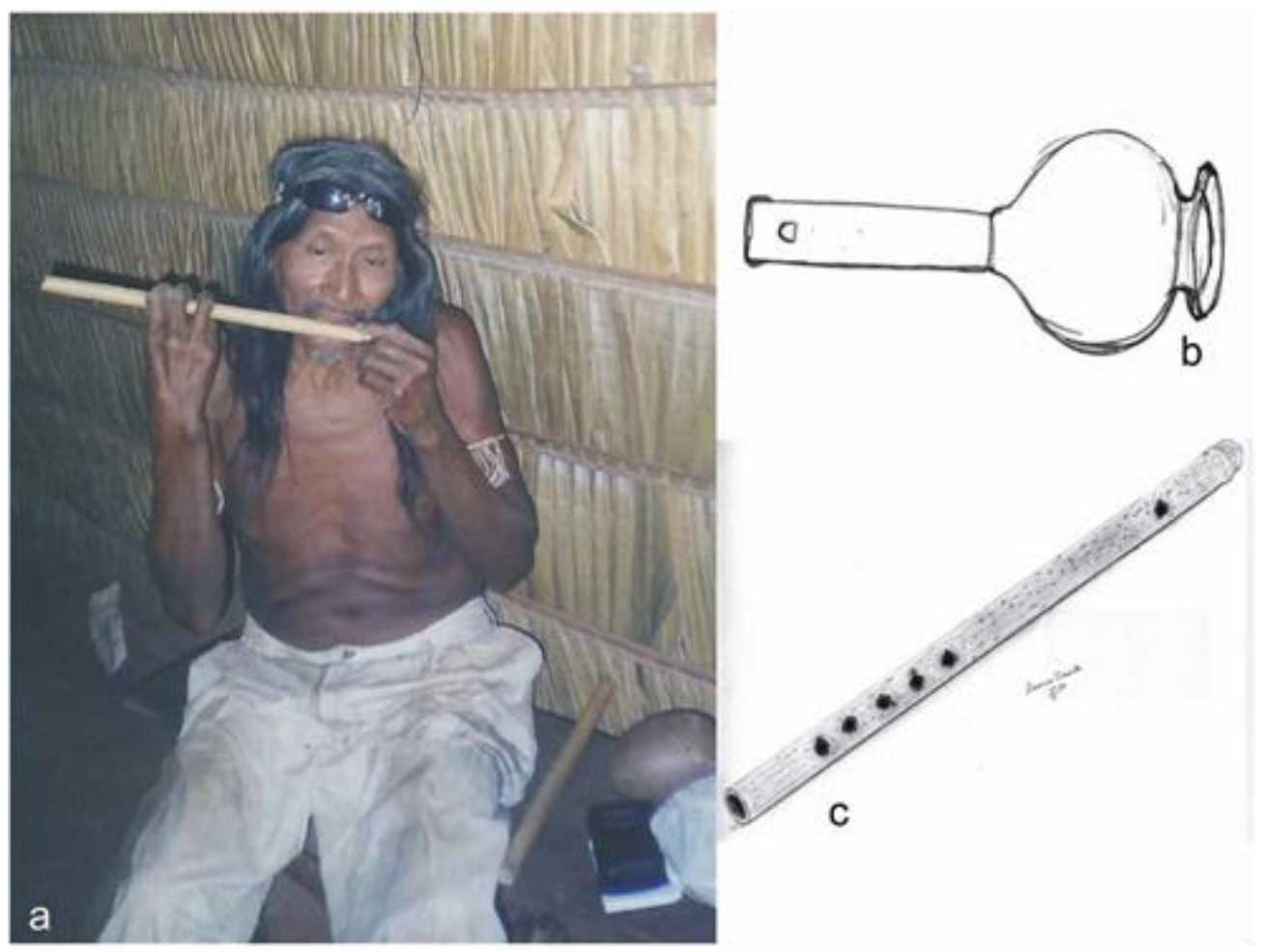

Fonte: (a) Wariní tocando a symyápy (flauta transversa), ao lado a symyápytáwa (trompete) desmontada. Autor: Matta da Silva, 28/02/2006. (b) Symyápytáwa. Autor: Hoytong, 19/04/2006. (c) Symyápy. Autor: Lima, 30/07/2006.

A casa chama atenção, pois se destaca em relação aos atuais modelos de habitação advindos com o contato dos Aikewára com os não índios. É um tipo de habitação que apresenta uma planta baixa retangular com abóbada ogival, composta por arcos ogivais em suas extremidades. $O$ teto e as paredes são cobertos por folhas de palmeiras, formando uma só unidade, e a construção possui uma única entrada que dá acesso ao seu interior, tendo uma porta removível constituída do mesmo material. Roque Laraia, quando realizou trabalho de campo entre os Aikewára, fez a descrição de uma moradia que apresentava uma forma diferente das outras duas habitações que compunham a aldeia. Pela semelhança dos dados, acreditamos se tratar da mesma moradia: 
Durante o abandono da primeira casa, todos os quarenta habitantes residiram em uma outra, de formato bastante diferente. O seu comprimento total era de 12,50 metros e a largura 6,70 metros. Era totalmente sustentada por dois moirões, de cinco metros de altura que sustentavam uma trava horizontal de 9,80 metros de comprimento. As suas paredes laterais eram constituídas por treze vigas de cada lado, tendo uma de suas extremidades fortemente fincadas ao solo e presas a pequenas traves verticais, e a outra extremidade presa a trave horizontal. Estas vigas serviam de suportes as folhas de palmeiras, destinadas a cobertura da casa. Desta forma, o teto e as paredes constituem uma só unidade e a casa, embora tenha uma planta plana retangular, apresenta uma forma de abobadada. Ressalta-se que uma pequena entrada lateral servia de porta (LARAIA, 1986, p. 60-61).

Ao entrar no interior da habitação, visualizei uma quantidade significativa de objetos (arco e flecha, cestos cargueiros, colares, araráw, maracás, braçadeiras, escudos, fotos, entre outros) utilizados pelos Aikewára. Entretanto, fixei atenção no sautikapeháw (casco de jabuti) suspenso de uma ponta a outra por um fio de algodão, contendo uma baqueta 23 empregada para percuti-lo.

Figura 3: Moradia tradicional e instrumento musical aikewára.
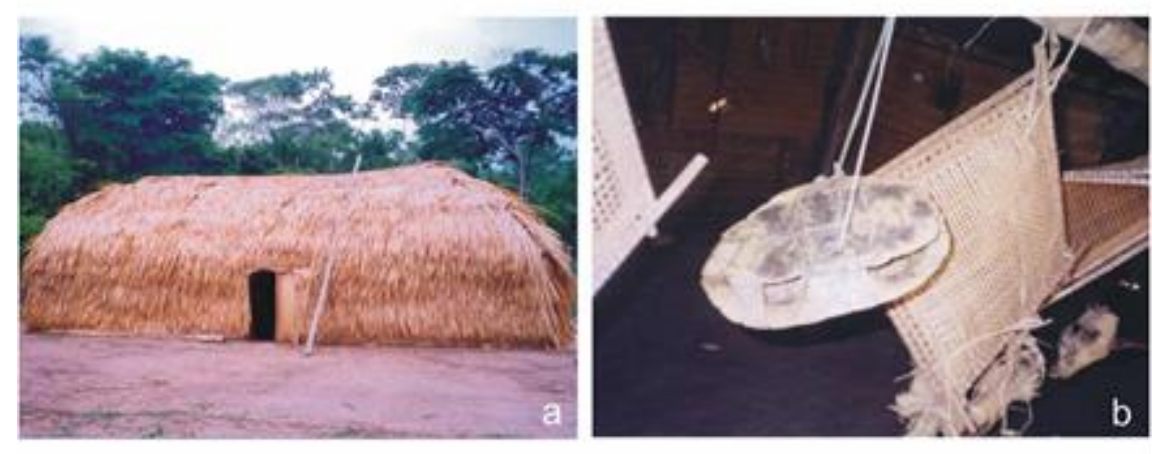

\footnotetext{
23،"Pequena vara de madeira com que se percutem os tambores. No caso do tambor de fenda, as baquetas são revestidas na extremidade de percussão com um capeamento de látex" (RIBEIRO, 1988, p. 211).
} 
Fonte: (a) Ogg'ete (casa de verdade). Autor: Arquivo aikewára, 2004. (b) Sautikapeháw (casco de jabuti) suspenso por fio de algodão. Autor: Matta da Silva 20/07/2005.

Informações sobre o instrumento foram encontradas em obras de referência e elas abrangem descrições minuciosas de instrumentos musicais, músicas, indumentárias, armas, trançados, rituais e danças, sendo que, de acordo com tais obras, as técnicas empregadas para se produzir o som do instrumento musical são diferenciadas. No estudo de Cameu (1977), esse instrumento aparece como de uso cerimonial entre os Tikuna na Festa da Moça Nova, sendo tocado por uma mulher, que utiliza uma baqueta para propagar o som. No caso de Koch-Grünberg (2005), a técnica empregada ocorre entre os Tukano e consiste em esfregar a palma da mão em uma abertura, antes revestida de breu e aquecida no fogo, produzindo um som semelhante a um grito; entretanto, o autor não fornece referência sobre quem e quando o instrumento é utilizado. Comparando o relato de Cameu com as considerações feitas pelos Aikewára, há certa semelhança em termos de emprego de técnica e no contexto onde o instrumento é utilizado. No passado, a prática de confecção do sautikapeháw era mais frequente, como se constata na narrativa de Awasaí sobre a origem e o uso do instrumento:

Os índios gritavam pro jabuti, né? Os índios que gritavam, naquela época jabuti era sabido, diz que eles gritavam porque queria comer jabuti. Eles gritava pro jabuti. Jabuti vinha correndo pro lado deles. Aí tem um que ia marrando, o outro virando pra ele, pra ele amarrar. Nesse tempo, naquela época, jabuti corria de gente. Aí eles gritava pra ele, ia correndo, vinha correndo pro lado dele. Aí esse índio virava pra, o outro marrava, o outro ia só virando, ia correndo atrás dele. Diz que ele vinha fazendo zuada, quebrando mata muito jabuti. Aí o outro amarrava, o outro ia virando, tinha uns que pegava o outro embora, amarrava um bocado. Hoje em dia diz que vai só caçar e fica quietinho, jabuti num corre mais. Tirava tudinho a perninha do jabuti, de tartaruga, tiravam só a carne dele, é, só a carne, depois deixava pá secá e tampava com cera de abelha pá dá som. Aí ele cantava canto do jabuti (AWASAÍ, entrevista em 12/02/2006).

Na sociedade aikewára, o instrumento é tocado por homem, que coloca o barbante em volta do pescoço e apoia o casco abaixo do peito, 
utilizando uma baqueta que o percute em toques fortes e consecutivos. O instrumento, segundo as informações dos Aikewára e na realização da dança do jabuti, durante minha segunda ida ao campo, no primeiro semestre de 2006, acompanha a marcação acentuada da perna direita no desenvolvimento da dança, se destacando, neste caso, em relação aos maracás, que apenas marcam de forma contínua o andamento do canto.

O que se constata, em relação aos objetos, é o fato de que eles assumem grande importância entre os Aikewára, assim como em outras sociedades indígenas, dando amplo destaque às formas, decoração, matérias-primas, inscrições em torno de sua estrutura, bem como o aspecto simbólico dos objetos, que podem estar ligados a concepções estéticas, religiosas e filosóficas do grupo. Tais fatores - simbólico, ornamental e de matéria-prima - são articulados em torno de conhecimentos dos experientes, que os utilizam na fabricação dos objetos, comunicando sentido e aspectos passíveis de identificação pela sociedade que produziu os objetos.

Diante da realidade apresentada, adoto o conceito de cultura proposto por Geertz (1978), o qual se refere a um sistema de concepções herdadas historicamente pelas gerações em formas simbólicas que permitem a comunicação entre as pessoas e a perpetuação de práticas desenvolvidas pelo conhecimento em relação à vida social. Deve-se mencionar que o conceito nasce a partir da constatação da necessidade em atribuir um significado às representações elaboradas pelos homens em sociedade.

Entre os Aikewára, os saberes em torno dos objetos permitem dar continuidade às práticas sociais, pois são passados pelos velhos às novas gerações através dos mesmos processos de aprendizagem aos quais foram submetidos: observação e execução. Nas conversas com os diferentes interlocutores aikewára, as referências em relação ao procedimento eram frequentemente verbalizadas e sempre direcionadas às pessoas experientes da aldeia. Como mostra o depoimento de Maironuhú:

Q uando a gente fazia antigamente, né, fazia uma coisa assim também para cantar música assim. Os velhos mostram né! Antigamente, até hoje, Mihó, Mihó, Sawara'á, Mikwá e Wariní [...] o meu pai também me ensinou, né? Mihó, Mihó ensina também, que é mais 
velho, meu pai já morreu, era pajé, também sabia fazer frecha, eu sei fazer flecha também [...] ensinava assim, mostrando como eles fazia, a gente olha, né? Gente mostra como gente faz tudo aqui, aí marra com essa linha, linha de, de, a gente compra isso daqui, né? Antigamente fazia memo era algodão mesmo que plantava, aí a gente bolava ela tudo e começava a fazê; minha vó memo que morreu, o nome dela era Wa'á, começou a fazer, fazia até rede disso também, antigamente fazia, até hoje faz também os mais velho, e a nossa tradição memo, antigamente já vinha assim mostrando memo, a gente aprende com mais velho mostrando [...] tô ensinando os meus meninos também, eu ensino, de vez em quando eu tô ensinando eles, aprendendo a língua também, a gente fala assim mostrando pra eles, é assim que meu pai fazia, né? Que era teu avô, né? Eu falava pra eles, eu falo até hoje, eu falo pra eles assim: tem que fala nossa língua, e não fala muito na língua do branco, antigamente falava só na língua de nós memo, não tinha aquele branco no meio [...] eles me vê quando faz, né? Fica aí perto, eu chamo e eles começam a aprender (MAIRONUHÚ, entrevista em 19/07/2005).

A socialização das práticas da sociedade começa desde a mais tenra idade de seus participantes. Nelas, os índios compartilham os costumes, crenças que medeiam a vida na aldeia, e que na floresta que revelam o modo de ser aikewára: seja na observação e confecção de um objeto, seja na forma de se aprender uma dança e cantar, contar histórias, falar a língua nativa. Um exemplo de socialização ocorreu durante a realização do sapurahár4, no qual os índios mais novos observavam os mais velhos durante uma dança que gerou comentários dos presentes, pois era a primeira vez que apresentavam à comunidade, no entanto era conhecida e praticada pelos experientes. Tal procedimento é reforçado pela explicação de Mihó, quando falava sobre como tinha aprendido a fabricar os instrumentos, bem como a cantar e dançar, remetendo-se aos

\footnotetext{
${ }^{24}$ Palavra que se refere às danças coletivas acompanhadas de cantos entoados pelo pajé. De acordo com os motivos de sua realização, que podem variar de uma grande caçada à expulsão das doenças na aldeia, para cada tipo de sapurahái há danças e cantos específicos, como das caças, dos casais, dos espíritos, entre outros. Das várias danças executadas pelos Aikewára, o sapurahái de karuára, ou Festa dos Karuára, como também se referem os indígenas, apresenta-se como o sapurahái mais importante, pois envolve o uso de práticas organizadas para o bom desempenho das ações entre os indígenas e os karuára, que retornam à aldeia por ocasião do ciclo ritual.
} 
ensinamentos adquiridos pela interação com os antepassados, pois em suas lembranças mencionava que

Os antigo, ele ensinava Musenái, Moroneikó25, Musenái ensinava também, fazia tudo direitinho para nós ver. Aí nunca deixamos de fazer. Capitão chamou pá cantá, dançar, repetindo muito vez, até nós aprender (MIHÓ, entrevista em 22/02/2006)

No depoimento acima, os atuais experientes aprenderam os ensinamentos que hoje repassam aos jovens mediante os conselhos e explicações dadas por Musenái, o grande chefe que detinha as funções de líder religioso e político entre os Aikewára. Nas conversas com os experientes, as lembranças vinculadas ao passado eram sempre presentes em seus comentários, fator explícito quando os índios as utilizavam para recordar acontecimentos ligados à vida na aldeia, que remetem ao aprendizado dos rituais, instrumentos musicais, entre outros. Em suma, os experientes acionavam a memória no sentido de comparar o presente com o passado, revivendo, via as lembranças, um modelo de prática almejada para as novas gerações; ideais que continuam a ser expressivos e atuantes mesmo com todas as mudanças sofridas pelo contato e no atual contexto vivido na aldeia, em que algumas famílias aikewára passaram a adotar outro sistema de crenças, com a presença da religião evangélica, ocasionando no abandono suas práticas sociais.

Retomando algumas ideias desenvolvidas, pode-se dizer que a prática cultural dos Aikewára, bem como nas demais sociedades indígenas, está ligada à adaptação ao meio ambiente que ocupam e de onde retiram parte da subsistência e as matérias-primas necessárias para a confecção de objetos de uso doméstico, ritual e lúdico. Por meio de práticas orientadas pelo conhecimento tradicional, o indígena estabelece uma relação dialógica com a natureza, mediante a apropriação e uso de seus recursos, com base em uma complexa lógica orientada pela experiência, fixada em formas perceptíveis, como se verifica em relação aos índios Ka'apor'26,

\footnotetext{
${ }^{25}$ Antigo líder aikewára reconhecido pelo seu saber e ensinamentos das práticas do grupo. Como forma de homenageá-lo, a escola da aldeia recebeu seu nome.

${ }^{26}$ Segundo Ribeiro, "Ka' apor" ou "Kaapor" é a autodeterminação do grupo e significa "povo da mata”. O termo urubu "[...] é um nome depreciativo, dado por gente que os odiava e temia, vendo-os como gente desumana e detestável" (RIBEIRO, 2008, p. 18). Portanto, o "Ka' apor" não tem relação com o nome
} 
[...] para sobreviver na mata os índios Urubu tiveram de recriá-la mentalmente, dar nomes às coisas, atribuirIhes sentido, encontrar-Ihes utilidade. De toda a infinidade de espécies que compõem a floresta amazônica eles selecionaram umas quantas, como os frutos alimentícios, as matérias-primas de seus artefatos, compreendendo desde madeiras para construir o arcabouço das casas ou simples arcos, até cipós e enviras para amarrar e tecer, folhas e palmas para embalar ou trançar, resinas e látex para colar, fazer fogo ou defumar, e, ainda, tintas, venenos, e muitos outros. [...] A mesma elaboração mental foi realizada em relação à fauna, esta também foi catalogada, recebeu nomes e significados. Elegeram algumas espécies para comer, cercaram outras de restrições e ainda proibiram completamente a utilização alimentar da maioria. Têm um profundo conhecimento dos hábitos não só das espécies de que se utilizam na alimentação ou para fabricação de adornos e artefatos, mas de quase toda a fauna regional (RIBEIRO, 1980, p. 35-36).

Munidos desse conhecimento, tanto os povos indígenas quanto outras populações tradicionais apresentam uma riqueza de saberes que as orienta em suas ações no cotidiano, sendo nesse caso o saber proveniente da coletividade, mesmo que este esteja centrado em uma única pessoa ou em um grupo de pessoas. Por isso, os velhos - pela experiência adquirida com o contato que mantêm com a natureza e pelos ensinamentos que outrora foram adquiridos via socialização com os antepassados - aprofundaram seus conhecimentos em determinados setores ou áreas do saber tradicional em relação aos demais indivíduos. Pelo grau de conhecimento que possuem, são expertos nos saberes ligados aos vários aspectos de sua sociedade, como ocorre entre os Aikewára.

Em diversas sociedades indígenas os velhos são estimados e tratados com respeito, em virtude de terem atingido um novo ciclo de vida, obtendo, assim, um novo status e um tipo de comportamento legitimado pela sociedade da qual fazem parte, como ocorre entre os índios Suyá estudados por Seeger (1980). O autor comenta que a posição destinada aos velhos varia de acordo com as regras sociais estabelecidas a grafia dos grupos nativos. Por isso os termos hifenizados para designar "Urubu-Kaapor". 
nas sociedades indígenas, sendo que em alguns grupos, como Guayaki, Siriono e Cubeo, os velhos são relegados ao abandono, desprezo e exclusão da vida social.

Na sociedade suyá, para além do novo status adquirido por essa classe de pessoas, que inclui tanto os homens quanto as mulheres, Seeger mostra que a atuação dos velhos é importante, pelo conhecimento que possuem em relação às práticas e aos saberes da sociedade. O que confere, a eles, prestígio perante os demais integrantes da sociedade, sobretudo em relação ao saber cerimonial:

Os velhos Suyá também são altamente respeitados pelo seu saber cerimonial. Como outras sociedades de língua Jê, os Suyá executam cerimônias bastante elaboradas com intervalos razoavelmente grandes. Algumas podem ocorrer só uma vez em 10 anos ou mais. Uma conseqüência direta dessas cerimônias pouco freqüentes mas importantes é que muitos dos rapazes, e até mesmo a maior parte dos adultos, têm um conhecimento incompleto a respeito de como executá-las. As pessoas velhas são necessárias para a execução correta e, em razão do seu saber, adquirem prestígio. Esse respeito pelos velhos pode parecer contraditório com o humor com que os wikényi [pessoas velhas] são tratados: os mesmos membros da comunidade que são respeitados também representam o divertimento e a comédia. Mas essas duas características não são incompatíveis para os Suyá. O atual especialista ritualístico procede cada vez mais como um wikényi (ele têm um filho casado e dois netos), sem perder nem um pouco do prestígio que têm como aquele que sabe como executar a maior parte das cerimônias importantes (SEEGER, 1980, p. 72).

Mastop-Lima, ao realizar pesquisa entre os Aikewára, também constata a importância e o respeito que os demais membros da sociedade têm para com os velhos. Tais pessoas são consideradas as mais sábias, possuem status diferenciado, pois dominam todo o conjunto de conhecimentos que se referem à identidade étnica e à constituição do ser aikewára:

Os Suruí Aikewára respeitam e valorizam os mais velhos e experientes do grupo, pois são eles conhecedores dos aspectos que constituem a identidade étnica do grupo; é a partir do conhecimento deles que os mais jovens são 
socializados em relação a ser Aikewára (MASTOP-LIMA, 2002, p. 84).

O fato é que, assim como na sociedade suyá, os velhos entre os Aikewára assumem grande importância em sua sociedade, devido à experiência adquirida e pelos ensinamentos que lhes foram outrora repassados, possibilitando fomentar entre as gerações mais novas o conhecimento utilizado nas atividades, que envolvem desde as práticas relacionadas ao cotidiano - como caça, pesca, agricultura - até aquelas que se tornam o foco do estudo, em torno dos instrumentos musicais aikewára. Com o referido grupo de interlocutores pude estabelecer contato e manter um diálogo, compartilhar de seus conhecimentos durante as entrevistas realizadas em torno dos saberes aikewára. Embora tenha conversado com pessoas de outras faixas etárias em várias ocasiões, concentrei o trabalho entre os velhos, tomados como interlocutores preferenciais, levando em consideração o grau de conhecimento sobre o assunto abordado.

\section{Entre instrumentos musicais, memórias e saberes}

A intervenção dos índios no meio ambiente, extraindo as matériasprimas para confecção dos artefatos e demais utensílios fabricados a partir do conhecimento existente da flora e da fauna permite a eles elaborarem via experimentação uma quantidade de objetos usados no cotidiano, nas danças e nos rituais. Dentre a variedade de objetos produzidos pelos índios, os instrumentos musicais também expressam a identidade cultural dos povos produtores, uma vez que

[...] são produtos de uma história: remetem-se às tradições identificadas pelo grupo como suas marcas distintivas, específicas de sua identidade; falam dos modos de viver e de pensar compartilhados no momento da confecção do produto material ou artístico ou da vivência da dramaturgia dos rituais, indicando uma situação no presente; em suas inovações, indicam as relações entre indivíduo e patrimônio cultural do grupo a que pertence [...] (VIDAL e LOPES DA SILVA, 1995, p. 371). 
Essas informações são fruto de registro da sociabilidade entre seus membros, envolvendo sua própria história e referindo-se à história dos artefatos, como as modificações processadas ao longo dos tempos entre as populações humanas. As populações tradicionais, ao produzir seus objetos, recorrem aos conhecimentos e saberes compartilhados entre si, sistematizando uma gama de informações para, então, confeccionar o produto final. Apesar da singularidade, centrada no indivíduo que está por trás na feitura do objeto, no geral quem aparece enquanto detentora de técnicas e procedimentos é a coletividade, pois

[...] a arte, nas sociedades indígenas, está comprometida com outros fins sociais que aqueles a eles atribuídos na sociedade ocidentais. É, até certo ponto, uma arte anônima, no sentido de que o sujeito criador são coletividades, ainda que seja sempre o indivíduo concreto quem dá a marca, o selo, o gesto particular. Neste sentido, caberia apontar os rituais como sendo, provavelmente, a forma mais condensada da arte indígena e da arte popular, por serem a síntese suprema de todas as manifestações de cultura corporal, de artes plásticas, de teatro, de poesia, de literatura, música e dança. Trata-se, sem dúvida, de uma experiência coletiva estetizada de uma maneira potente, concisa, densa (VIDAL e LOPES DA SILVA, 1995, p. 373).

Diante da realidade apresentada, o conhecimento tradicional fundamenta-se em princípios e práticas culturais, transmitidos de geração a geração. O saber tradicional envolve prática e exercício intelectual constantes de investigação e inovação (CARNEIRO DA CUNHA e ALMEIDA, 2002). Por meio do conhecimento dos velhos acionado pelas lembranças do tempo antigo se destaca a aprendizagem em torno dos instrumentos musicais como modelo de socialização intergeracional.

Os conhecimentos apreendidos "antigamente" ou "naquele tempo", como se referem os Aikewára, acionam lembranças do passado vivido na aldeia, onde as práticas rituais, os cantos, as danças ligavam a pessoa de Musenái aos atuais especialistas, ensinando-os a cantar e a confeccionar os instrumentos musicais. A própria ressignificação dessas atividades entre os velhos, quando acionam o passado no presente, exterioriza um sentimento de identidade, de saudade, como forma de socializar os 
conhecimentos tradicionais empreendidos pelo antepassado junto aos mais jovens.

A memória enquanto fenômeno social torna-se relevante pela possibilidade de mostrar a caracterização de uma construção coletiva ou individual das pessoas, dando, assim, vida aos acontecimentos passados a partir do acionamento de suas lembranças. Halbwachs, ao se referir ao ato de lembrar, comenta que

[n]ossas lembranças permanecem coletivas e nos são lembradas por outros, ainda que se trate de eventos em que somente nós estivemos envolvidos e objetos que somente nós vimos. Isto acontece porque jamais estamos sós. Não é preciso que outros estejam presentes, materialmente distintos de nós, porque sempre levamos conosco e em nós certa quantidade de pessoas que não se confundem (HALBWACHS, 2006, p. 30).

No contato que mantive com os velhos pude perceber a inclusão de pessoas em seus depoimentos quando se recordavam dos ensinamentos a partir dos quais foram socializados. Comumente nomes como Sawara'á, Mihó, Wariní e Awasaí eram mencionados, tomando como referência a pessoa de Musenái, remetendo ao tempo antigo. A partir da interação dos velhos com Musenái, revive-se o passado, atualizando-o na experiência que vivenciaram com os processos de aprendizagem em relação aos cantos, aos mitos, às danças e à construção dos instrumentos musicais.

Ao levar em consideração os argumentos de Bosi (1994) sobre os referenciais acionados pela memória dos velhos na sociedade capitalista, Mastop-Lima (2002) faz um contraponto destes referenciais com os utilizados pelos velhos aikewára. Para os velhos na sociedade capitalista os referenciais são família, religião, classe social, entre outros. Para os Aikewára, os referenciais abrangem o tempo antigo e o espaço da floresta, que caracteriza o território indígena, viabilizando a interação dos Aikewára com os elementos naturais e seres que nele habitam.

Para os Aikewára, rememorar o tempo antigo, tendo como viés suas práticas culturais, caracteriza uma forma de afirmar-se enquanto membros de um grupo étnico a partir de um sentimento de identidade, diria também de saudade. O que se torna possível a partir das lembranças 
do passado - que incluíam o antepassado, familiares e práticas socais registradas nos depoimentos de Arihêra e Apí:

Ficava sentado contando história, nem naquele tempo assim, criança no meio conversando tudo não, ficava tudo calado, respeitava capitão. De noite contava história, eu ficava com Musenái, com meu pai, com minha mãe, minha mãe eu ficava conversando com ela, contava e eu só escutando. Ele não tinha muita gente para insinar, como é que vivia (ARIHÊRA, entrevista em 31/03/2006).

Sapurahái antigamente dançava, mesmo, até de manhã, começava cinco horas, cinco da tarde primeiro até noite. Aí para primeiro pra banhá tudo. Aí começou cinco horas. Aí dançou, dançou. Aí para de novo pra comer alguma coisa. Aí torna de novo, de novo até de manhã, assim mesmo, assim vem amanhecendo, mesmo, eles dançavam a noite todinha (APÍ, entrevista em 19/07/2005).

Esse sentimento de saudade ao qual me reporto em relação aos Aikewára, quando falam das experiências do passado e das pessoas com quem tiveram contato, também se faz presente em outras sociedades indígenas, havendo variações das formas como eles são transmitidos, podendo envolver o discurso, o sonho e as músicas. O sentimento de saudade também se encontra presente nas músicas compostas pelos os índios guarani-kaiowá do Mato Grosso do Sul. Entre eles, Montardo (2002) percebeu o uso de práticas destinadas a trabalhar as emoções como a tristeza e o abandono utilizando conversas, passeios, jogos de corridas e as músicas ligadas ao referido sentimento, envolvendo fatos passados, pessoas com quem conviveram e as experiências de contato com os brancos. A música possui a finalidade de - a partir de sua experiência no ritual jeroky - reviver os fatos passados, fazendo com que os índios adquiram autocontrole das emoções, ocasionando - entre outras transformações provocadas no corpo - a passagem da tristeza para a alegria.

Na relação com os antepassados, os Aikewára mencionam, em seus depoimentos, a figura de Musenái, estendendo sua ligação a Moroneikó, enquanto aprendiz deste último, e com o qual aprenderam e passaram a socializar os conhecimentos relativos aos cantos, fabricação dos 
instrumentos musicais e mitos para as novas gerações, seguindo os mesmos processos aos quais foram submetidos. Como se constata no depoimento do um jovem Arukapé em relação à socialização do conhecimento:

Musenái, Musenái era o cacique da aldeia aqui. Antigamente ele era cacique, ele que ensinou tudo para esses mais velhos como o Awasaí, Mikwá, Marahí, Mihó, Wariní, Sawara'á. Ele ensinou essas coisas aí que hoje em dia nós sabemos da nossa cultura, que ele ensinou para esses velhos aí, que esses velhos tão repassando para nós igual ele repassou para esses velhos, né? Musenái, ele era cacique, mas só que hoje em dia nós temos o nosso cacique, né, igual, o Mahú, mas só que hoje nós temos os nossos guerreiros que é Sawara'á, nós temos o pajé que é Awasaí. E antigamente, Musenái, ele era cacique, ele era pajé, ele era guerreiro, ele ensinava, ele era um bocado de coisa, mas ele era sozinho, né? Ele ensinava a tirar espírito mal dos índios, ele era guerreiro também porque ele sabia como cuidar da comunidade, né, direito, não deixava a comunidade, não deixava a comunidade dele em desunião. Aí ele ensinou tudo isso pros mais velho repassar pra nós hoje (ARUKAPÉ, entrevista em 20/07/2005).

O aprendizado contava com a participação de grande parte da coletividade reunida no pátio da aldeia, porém não tinha um período para ocorrer, tudo acontecia por iniciativa de Musenái convocando um grupo de índios para ensinar, independente de horário, fosse de manhã, à tarde ou à noite, por ocasião do sapurahái, quando passavam a noite cantando e dançando. De acordo com as informações dos velhos, Musenái, durante a socialização das práticas, demonstrava o modo de fazer referente aos instrumentos musicais, cantos, mitos e histórias relativos aos Aikewára, como recorda Arihêra:

[...] ele contava história, dançava, ele sabe cantá. Diz que Moroneikó contava tudo para ele, diz que Moroneikó ensinava no tempo que teve aquela enchente que matou todo mundo, diz que se acabou com água, o pessoal se acabou com água, teve o primeiro acontecimento da, de acabar o mundo 27 , né? Que falou que acabou o mundo. E aí foi ensinando muita coisa pro Musenái também o

\footnotetext{
${ }^{27}$ Refere-se ao mito de origem dos Aikewára. Sobre o referido mito, consultar Mastop-Lima (2002) e Matta da Silva (2007).
} 
Moroneikó. E o Musenái decorou tudo na cabeça dele, para ensinar os outro, que somos nós, né? Esses índios mais velhos (ARIHÊRA, entrevista em 31/03/2006).

A forma com que os ensinamentos são realizados, tanto antigamente quanto hoje, segue os mesmos processos, os quais são baseados na observação, experimentação e audição, processos que orientam o conhecimento tradicional articulado em torno da linguagem. A língua falada torna-se o principal veículo de expressão da linguagem, pois

[...] a língua é efetivamente o instrumento básico da transmissão da cultura, da socialização, portanto, tendo ela, ainda mais, a característica de sistema conversor (tradutor ou indicador) de todos os outros sistemas, isto tudo levando a acreditar não ser ela um sistema de conhecimento definido por objeto específico mas, sim, por abordá-los especificamente, no caso, taxonomicamente (MENEZES-BASTOS, 1978, p. 42).

Por isso, a linguagem para os grupos indígenas torna-se um mecanismo pelo qual se transmite e se obtém conhecimento, armazenado na memória dos indivíduos, socializados a partir das práticas vigentes na sociedade a que pertencem, envolvendo significados e concepções, em relação a diversos aspectos da vida social. Caso similar se constata entre os instrumentos musicais, destacando, neste caso, o significado e a grande importância que o wapusá e a symyápytáwa assumem em contextos específicos na vida dos Aikewára.

Os instrumentos musicais aikewára estão distribuídos em dois grandes grupos aerofones e idiofones, segundo a classificação elaborada por Hornbostel e Sachs (1961). O esforço empreendido pelos pesquisadores no início do século XX demonstrou a preocupação desses estudiosos em classificar os instrumentos musicais de forma apropriada, ressaltando a necessidade de se complementar o trabalho iniciado pelos autores acima, conforme o desenvolvimento de outras pesquisas.

O trabalho de Seeger (1987) sobre a classificação dos instrumentos musicais indígenas constitui um novo tipo de abordagem para o estudo destes objetos, apresentando informações importantes que levam em consideração o contexto em que estão inseridos, o processo de fabricação, matéria-prima, quem faz, em que momento são tocados, 
como são tocados. Passando para aspectos técnicos como: afinação, tonalidades, alternância no acompanhamento das músicas e o simbolismo que envolve alguns instrumentos como o maracá, a flauta e o trompete nas Terras Baixas da América do Sul (TBAS). Todo esse esforço visa fornecer uma compreensão e revelar o lugar dos instrumentos e da música na vida das sociedades indígenas.

Ao estudar os marakatap (instrumentos musicais) entre os índios kamayurá, Menezes Bastos (1978) analisa aspectos para o seu entendimento musicológico, como: classificação, construção, afinação e execução. Além disso, observa a existência de desenhos que fazem parte desses objetos. Em seguida apresenta as etapas que são realizadas por um ou mais especialistas, que se encarregam de executá-las; por exemplo, a afinação, cuja responsabilidade é do mestre de música, que realiza este procedimento em dois momentos, sendo um durante a construção e outro antes das execuções das músicas. Entre os Aikewára, os especialistas participam de todas as etapas de construção dos instrumentos, pois não há uma etapa que exija conhecimentos específicos, como no caso apresentado entre os Kamayurá. Todos os especialistas aikewára dominam as técnicas que vão desde a construção até a execução das músicas.

O primeiro grupo é formado pelos aerofones. Abrange instrumentos de sopro, que emitem sons a partir da vibração do ar no seu interior, no qual se encontram, entre os Aikewára, as symyá (flautas), que formam um complexo de cinco flautas com terminações específicas: symyá (flauta reta), symyápy (flauta transversa), symyápéw (flauta de pã) ${ }^{28}$, symyápytáwa (trompete). O segundo grupo é formado pelos idiofones. Abrange os instrumentos de percussão, que emitem som a partir da vibração da matéria-prima das quais são confeccionados, como o sykã (chocalho em cacho), o sautikapeháw (tambor de carapaça) e o wapusá (chocalho ovóide ou globular). Sobre o wapusáe, posteriormente,

\footnotetext{
${ }^{28}$ Em relação a esta terminologia dada ao instrumento encontramos três exemplares que recebem essa mesma denominação. O primeiro com dois tubos, o segundo com três tubos e o terceiro com seis tubos. Cameu (1977) informa um exemplar de flauta de pã comum com a presença de um ou dois tubos conjugados que foram encontradas entre os Suruí, do Pará, Apinajé, de Goiás, Kepkiriwat, do território de Rondônia, entre outras. Porém não constam nos registros da autora informações sobre a existência do segundo e terceiro exemplares que encontramos em nossa pesquisa entre os Aikewára.
} 
a symyápytáwa se fará considerações a respeito da importância que apresentam para os Aikewára.

\section{O chocalho e o trompete aikewára}

$\mathrm{Na}$ vida social e em diversos rituais das sociedades indígenas brasileiras, o maracá está presente no desenvolvimento de práticas de cura, rituais de nominação e de iniciação masculina e feminina, na evocação de espíritos, entre outros, além de exercer papel importante no andamento do canto e nos movimentos das danças. Esse instrumento musical está ligado a diversas concepções de ordem simbólica, como: objetos sagrados, o centro da cabeça, o centro do universo e/ou seres vivos29. Devido à importância que apresentam para as sociedades indígenas, os maracás estão cercados de explicações a partir de narrativas sobre suas origens, significados, funcionalidades e, em determinados casos, proibições sobre quem pode manuseá-los e/ou vêlos.

No que se refere aos Aikewára, os índios contam que os antigos coletavam no interior da mata um fruto denominado wapusáeté (wapusá de verdade), que brota de um cipó durante a época do verão e que deu origem ao nome do instrumento musical, sendo utilizado na fabricação dos primeiros wapusá. Devido a sua estrutura ser bastante frágil, provocando rachaduras e a quebra total da caixa acústica a qualquer queda, os índios passaram a experimentar outros materiais mais resistentes, encontrando na cuité/cuia a matéria-prima ideal para a feitura do instrumento musical.

O wapusá é confeccionado com os seguintes materiais: cuité [cuia] (Crescentia cujete L.), sementes de mungulú, ilimó [fios de algodão], akamacyrona [taquara] (Guadua angustifólia Kunth) e penas de arara. Constitui-se em recipiente feito de cuité (cuia), no qual são depositadas sementes de mungulú, que, ao serem movimentadas, produzem sons. 0 cabo é revestido por fios de algodão encordoado, junto com penas de arara, que integram a decoração. Instrumento produzido e usado por

\footnotetext{
29 Sobre o assunto consultar os trabalhos de Staden (1988), Lery (1941), Vidal (1977), Bodin (1978), Menezes Bastos (1978), Metraux (1979), Viveiros de Castro (1986), entre outros.
} 
homens nas danças em geral, para brincar, para aprender a tocar e exclusivamente no sapurahái de karuára30.

Figura 4: Fruto do wapusá e instrumento musical aikewára.

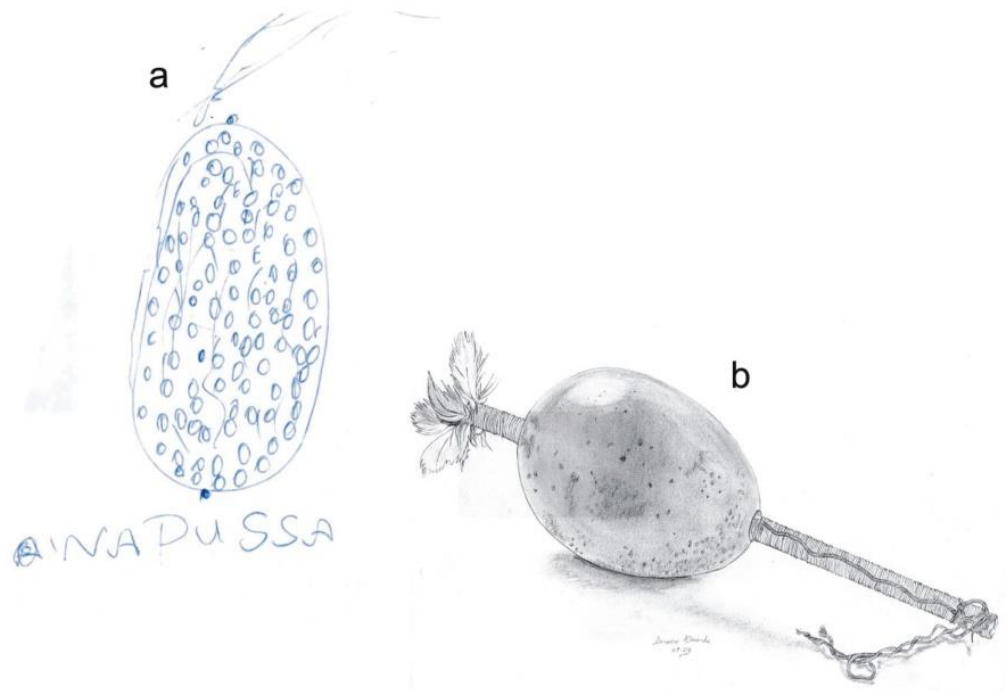

Fonte: (a) Wapusáeté (wapusá de verdade). Autor: Hoytong, 19/04/2006. (b) Wapusá. Autor: Lima, 13/07/2005.

No ritual do sapurahái de karuára, os araráw e os wapusá tornamse objetos sagrados. Ao deixarem as casas dos indígenas passam a ocupar o interior da tukasá31 e só saem deste local a cada reinício da dança; não podem ser tocados ou manuseados fora do contexto ritual. Se, entretanto, um índio infringir a regra, ficará doente e morrerá, caso não haja intervenção do pajé. Se pensarmos nos termos de Durkheim (1989), tais objetos adquirem caráter sagrado, como algo que deve ser mantido à parte, isolados dos demais objetos e das pessoas. Esse

\footnotetext{
${ }^{30}$ Abrange a categoria de espíritos especiais que difere dos asonga e heróis míticos identificados por Laraia (1986), pois são temidos pela capacidade de provocar doenças e mortes, caso sua entrada no plano habitado pelos Aikewára não seja controlada a partir dos procedimentos rituais (canto, fumo e gritos) exercidos no ritual.

${ }^{31}$ Casa ritual que simboliza a morada dos karuára, sendo semelhante a uma gruta. Sua estrutura é toda revestida de folhas de palmeiras e apresenta uma entrada como via de acesso e saída dos espíritos no plano habitado pelos indígenas, que por meio do canto e do fumo ritualizam a entrada e a permanência dos karuára na aldeia de forma controlada. É um espaço vedado às mulheres, pois, segundo a crença, elas podem ficar doentes, podendo até morrer caso entrem no seu interior ou toquem nas palmeiras que revestem a tukása.
} 
processo mostra todo um cuidado que os Aikewára, durante o ritual, devem manter com os elementos de caráter simbólico, os quais estão relacionados aos karuára (espíritos especiais), neste caso a tukasá (casa ritual), os araráw (adorno de cabeça), petymahów (cigarro de palha) e os wapúsa (maracá).

Como objetos da cultura material dos Aikewára, o araráw e o wapusá também pertencem aos espíritos, mas é por meio do wapusá, associado ao canto entoado no início do ritual, que os karuára são chamados para a dança. Essa categoria de espíritos é reconhecida pela sua capacidade de se materializar - entre outras formas ${ }^{32}$, como humano - no plano habitado pelos indígenas, assumindo as características de um aikewára, pois apresentam-se pintados, usando o araráwe empunhando o wapusá.

Como se observa, a produção dos instrumentos musicais apresenta uma sistematização de saberes para se processar a feitura do instrumento, e isso requer: domínio da natureza, conhecimento do território, escolhas de matérias-primas e também as técnicas exploradas para a obtenção de sons diversificados para cada tipo de instrumento, variando a altura (grave-agudo) e o timbre - parâmetro que se caracteriza como o principal elemento fundador das músicas aerofônicas dos índios da Amazônia.

No artigo bibliográfico sobre as músicas das sociedades tupiguarani, Menezes Bastos e Piedade (1999) discutem, a partir do estudo de Beaudet (1983) sobre a música wayãpi, questões relacionadas a aspectos da abordagem etnomusicológica (forma, conteúdo, contexto e tradução), estabelecendo comparações em torno das músicas das sociedades tupi-guarani, que apontam para grandes temas (canibalismo, guerra, xamanismo, morte e construção de pessoa) ordenados pela musicalidade. Além de destacar a importância do timbre como dimensão fundamental na música de orquestra de clarinete tule, apontam o aspecto simbólico em torno dos instrumentos musicais, sobretudo do complexo de flautas sagradas dispersas pelas TBAS, mas que não se restringe somente a esse grupo de instrumentos aerofones, podendo ocorrer entre os idiofones, como os maracás.

\footnotetext{
${ }^{32}$ De acordo com informações obtidas entre os experientes, os karuára podem se apresentar sob a forma humana no interior da mata, como fogo ou fumaça no céu, e na figura do sapo kururú.
} 
O aspecto estrutural "visibilidade" e "audibilidade" em torno das flautas sagradas, de acordo com Menezes Bastos e Piedade (1999), não foi encontrado entre as mulheres por Beaudet durante seu estudo envolvendo a música dos clarinetes tule entre os Wayãpi. Semelhante aspecto foi observado entre os Aikewára em relação às flautas, que podem ser visualizadas e ouvidas sem qualquer proibição para as mulheres. Além disso, pela nossa pesquisa realizada até o presente momento, não foram encontradas evidências mitológicas que se liguem a esses objetos.

O que encontramos foram depoimentos relacionados à symyápytáwa, que no passado era tocada em uma antiga prática de sociabilidade, envolvendo um grupo de índios que saía da aldeia carregando cestas farinha e banana e se dirigia até o local da derrubada das árvores na mata (local que posteriormente servia como roça) para dançar, cantar e trocar alimentos com outros índios que se faziam presente. No passado tal prática era comumente exercida pelos indígenas, que faziam da atividade de subsistência um grande acontecimento, que envolvia a mobilização de homens e confecção dos artefatos (cestas), destacando-se neste processo o uso da symyápytáwa, conforme o depoimento de Arihêra:

[...] Symyá eles fizeram para eles comemorar a dança deles, né? Tocando com symyá. Diz que eles faziam essa cesta aqui como se fosse saco, que diz que era feito com esse material aqui nós chama pariri, pariri que nós chama e kamará chama parece que arumã. É tipo assim banana brava, mas só que elas têm as folinhas assim, têm um pezinho compridinho, sabe? É fininho o pezinho dele. Aí fica um montinho, só aquelas folhinhas assim, é chama arumã. Aí diz que eles faziam grande desse aqui, a cestinha grande para guardar farinha, para eles poder cantar e tampar com a folhinha dela. E aí, depois, diz que era para comemorar a dança que é feita essa cesta; aqui, é, botava farinha. Aí capitão mandou para eles levar, carregar lá na roça que ele tá derrubando. Aí levava banana, levava para eles comer. Diz que eles fazia essa cuia, que era para instrumento. Aí diz que que eles iam tocando, tocando. Aí diz que eles tava lá cortando o pé de uma árvore grande, sabe? Aí quando caía; que aí diz que eles iam tocando até que chegava, na hora que eles chegavam lá onde que ele tinha cortado aquele pau. Derrubava o pau e aí diz que eles chegavam 
lá e diz que eles comemoravam a queda, quedona do pau, né? Aí diz que eles comemoravam cantando e tocando essa música dele e a symyá, que é feita de cuia e o beiço é assim bem grande assim, largona assim, que é feito de cera (ARIHÊRA, entrevista em 21/03/2006).

A importância que a symyápytáwa assumia, nesse contexto, para os Aikewára é que ela demarcava o fim de uma etapa (derrubada das árvores) e o início de outra, envolvendo a atividade de queima do terreno a ser utilizado posteriormente para o plantio, congregando os participantes, em meio à execução do instrumento, a cantos, danças e consumo de alimentos. Segundo os Aikewára, esse instrumento apresenta outras denominações, como symyáeté (flauta de verdade), devido a se destacar pelo formato em relação às demais, e symyáhú quando comparam o som emitido pelo instrumento ao barulho de um avião.

Confecccionada com puná [taquara] (B. vulgaris Schrd), cuité [cuia] e e hyratõma [cera de abelha], a symyapytáwa ${ }^{33}$ é constituída por um tubo extenso e provida de embocadura situada próxima à extremidade distal. O cuité serve de caixa acústica que amplifica o ar soprado pelo interior da taquara, apresenta dois orifícios perfurados e posicionados na mesma direção. O primeiro, aberto em sua base, acopla o tubo de puná, fixado com ehyratõma (cera de abelha). O segundo é aberto na parte superior do cuité, é uma extensão do primeiro orifício, permitindo a passagem do ar, auxiliada pelo defletor de cera de abelha situado na parte externa do cuité. $\mathrm{O}$ instrumento foi produzido no passado por homens, sendo usado no deslocamento da aldeia até o local da derrubada das árvores na mata e na dança de roça.

Os instrumentos musicais imbricam vigor e a beleza da expressão artística da sociedade indígena produtora, marcada pelo simbolismo presente também em outros objetos próprios de sua cultura. Com isso, todo um universo de significado e sentido torna-se conhecido, à medida que aprendemos a olhar para além da materialidade do objeto, o que implica em conhecer os processos de transmissão de saberes e de visão de mundo que envolve os instrumentos musicais aikewára.

\footnotetext{
${ }^{33} \mathrm{O}$ instrumento apresenta as seguintes medidas: 1centrímetro de orifício labial, 5 centrímetros de diâmetro da taquara; 34 centrímetros de diâmetro do cuité: e 6,5centrímetros de diâmetro do defletor. Todo o instrumento apresenta 41centrímetros de comprimento.
} 
Figura 5: Instrumento musical aikewára e indígena.
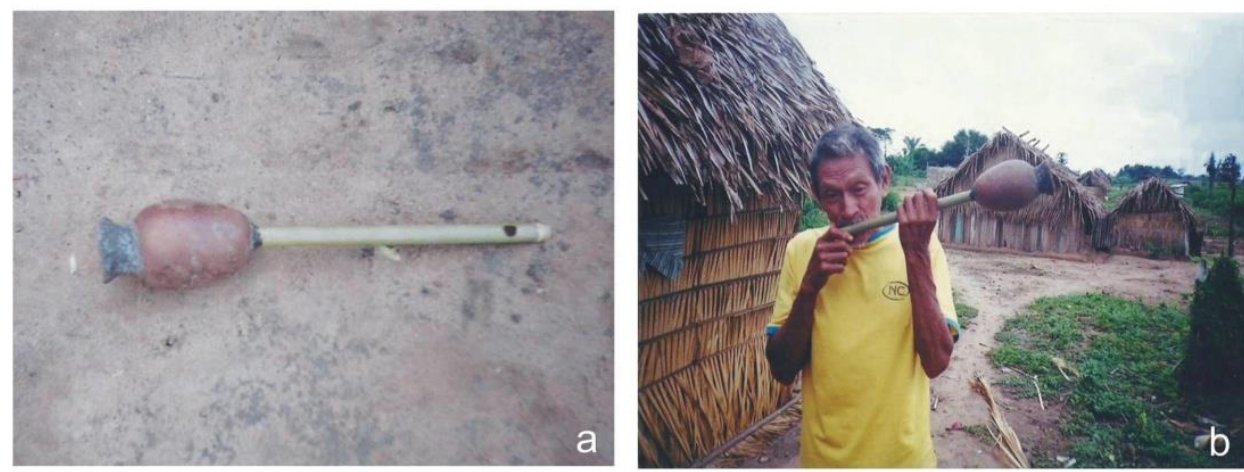

Fonte: (a) Visão da symyápytáwa. (trompete) Autor: Matta da Silva, 28/02/2006. (b)

Sawara' à mostrando a técnica de tocar a symyápytáwa. Autor: Matta da Silva 28/02/2006.

\section{Conclusão}

Conhecimentos tradicionais aplicados em diversos setores da vida cotidiana envolvem a constituição de saberes provenientes da experiência de seus membros, mediante a interação com o meio ambiente e com seres espirituais. Dado o amplo conhecimento adquirido das práticas do grupo, os velhos são responsáveis pela manutenção dos saberes, pois os socializam com os demais membros da sociedade aikewára.

Nas lembranças em torno dos conhecimentos tradicionais, os velhos enfatizam a aprendizagem em conjunto feita com o antigo cacique Musenái, estimulando-os nos processos relacionados aos cantos, aos mitos, às danças, à construção de instrumentos musicais, entre outras práticas que envolvem a constituição do ser aikewára. Na volta ao passado, por meio de fatos que os ligam às práticas culturais e principalmente à pessoa de Musenái como um grande referencial a ser 
seguido pelos demais índios, os velhos estimulam aos mais jovens nos aspectos referentes às danças, aos cantos, à produção dos instrumentos musicais e à própria ressignificação dessas atividades. Quando acionam o passado no presente, indicam o sentimento de identidade, de saudade, como forma de socializar os conhecimentos tradicionais empreendidos pelo antepassado.

Os objetos são produtos de uma história e estão relacionados a valores, costumes e às tradições do grupo. A tradição envolve processos de transmissão de saberes e a socialização de uma geração que repassa seus conhecimentos tradicionais a outra geração "[...] realizado através de observação e imitação, perpetuam-se em grupos tribais por gerações determinadas maneiras de fazer as coisas [...]" (HARTMANN, 1976, p. 193). Particularmente dois instrumentos musicais em contextos específicos assumem grande importância na vida dos Aikewára, seja na atividade agrícola - demarcando a passagem de uma etapa do processo de trabalho para outra, como ocorria com a symyápytáwa -, seja na prática ritual - que confere ao wapusá um caráter sagrado, por ser um dos elementos simbólicos ligados aos karuára-, conforme se abordou no artigo. A partir desses modos de saber (fazer) é que os Aikewára imprimem suas marcas, se distinguem etnicamente e perpetuam suas memórias atualizando-as, seja na produção dos instrumentos musicais ou em qualquer outro tipo de atividade.

Os conhecimentos sobre os instrumentos musicais envolvem desde a escolha das matérias-primas, como a própria habilidade em se trabalhar os materiais, a precisão dada aos cortes, às perfurações e às amarrações feitas nos objetos, até o conhecimento de seus contextos e de suas técnicas de criação e execução musical. Isso mostra a profundidade do conhecimento indígena que se processa e se renova a cada atividade de produção dos instrumentos musicais, seja para quem os faz, seja para quem os apreende. Por esses processos, os Aikewára têm a dimensão do que produzem e por que produzem, conhecimentos pelos quais educam crianças e jovens. 


\section{Referências bibliográficas}

BALDUS, Herbert; WILLEMS, Emílio. Dicionário de Etnologia e Sociologia. São Paulo/Rio de Janeiro/Recife/Porto Alegre: Biblioteca Pedagógica Brasileira/Companhia Editora Nacional, 1939.

BARTH, Fredrik. O guru, o iniciador e outras variações antropológicas. Rio de Janeiro: Contra capa, 2000.

BEAUDET, Jean-Michel. Les Orchestres de Clarinettes Tule des Wayãpi du Haut Oyapock. 1983. 431 f. Tese (Doutorado em Antropologia) - PPGA, UP, Paris, [1983].

BELTRÃO, Jane. Coleções etnográficas: testemunhos da educação, história e registro da diversidade na Amazônia. Belém: UFPA, 2000 (mimeo).

Coleções etnográficas: chaves de muitas histórias. DataGramaZero, Rio de Janeiro, v. 4, n. 3, n.p., 2003. Disponível em: www.dgz.org.br/jun03/F_I_art.htm. Acesso em: 12 fev. 2005.

BODIN, Max. Dicionário de tupi moderno. São Paulo: Conselho Estadual de Artes e Ciências Humanas, 1978.

BOSI, Ecléa. Memória e Sociedade: lembrança de velhos. São Paulo: Cia. das Letras, 1994.

CAMEU, Helza. Introdução ao estudo da música indígena brasileira. Rio de Janeiro: Conselho Federal de Cultura, 1977.

CAMPELO, Marilu Márcia. Coleções Etnográficas Arthur Napoleão Figueiredo e Anaiza Vergolino-Henry: patrimônio simbólico religioso e memória afro-brasileira na Universidade. Relatório (Relatório de Pesquisa Inédito). Belém do Pará: UFPA, 2007.

CAMPELO, Marilu Márcia; ALBUQUERQUE, Shirley Muryel Ferreira. Coleção Etnográfica Arthur Napoleão Figueiredo e Anaíza Vergolino e Silva: patrimônio simbólico religioso e memória afro-brasileira na universidade: as indumentárias e adornos nas religiões afro-brasileiras no Pará. In: $13^{\circ}$ Congresso Brasileiro de Folclore, Fortaleza. $13^{\circ}$ Congresso Brasileiro de Folclore. Fortaleza: Comissão Cearense de Folclore, 2007.

CAMPOS, Alessandro Ricardo Pinto. Cultura Material de Terreiros: um estudo sobre a coleção etnográfica afro-brasileira da UFPA. 2014. 120 f. Dissertação (Mestrado em Ciências sociais) - PPGSA, UFPA, Belém do Pará, PA, [2014].

Cada peça tem sua História: contextualizando as peças Afro-religiosas da Reserva Técnica do Laboratório de Antropologia Arthur Napoleão Figueiredo/UFPA. Projeto (Projeto de Doutorado em Ciências Sociais). Belém do Pará: UFPA, 2015. 
CARNEIRO DA CUNHA, Manuela; ALMEIDA, Mauro Barbosa de (Org.). Enciclopédia da Floresta: o Alto Juruá: práticas e conhecimentos das populações. São Paulo: Cia. das Letras, 2002.

DAMATTA, Roberto. O ofício de etnólogo, ou como ter 'Anthropological Blues'. In: OLIVEIRA, Edson Nunes (Org.). A aventura sociológica. Rio de Janeiro: Zahar, 1978. p. 23-35.

DOMINGUES-LOPES. Rita de Cássia. Desvendando significados: contextualizando a Coleção Etnográfica Xikrín do Cateté. 2002. 160 f. Dissertação (Mestrado em Antropologia) - PPGCS, UFPA, Belém do Pará, PA, [2002].

DOMINGUES-LOPES. Rita de Cássia et al. Coleções etnográficas: Etnologia Indígena, População Urbana/Cultos Afro-brasileiros e População Interiorana. Belém: UFPA, 2003.

DOMINGUES-LOPES. Rita de Cássia; BELTRÃO, Jane. Felipe. Descobrindo brinquedos indígenas em coleções etnográficas. In: IV Semana de Museus Preservação em museus: identidades, políticas e memórias. São Paulo, p. 24-25, 2003.

DOMINGUES-LOPES. Rita de Cássia; SILVA, Gilmar Matta. Instrumentos Musicais e de Sinalização: Coleções etnográficas da Universidade Federal do Pará. In: MOREIRA, Eliane et al (Org.). In: Anais do Seminário Patrimônio Cultural e Propriedade Intelectual: proteção do conhecimento e das expressões culturais tradicionais, realizado em Belém no período de 13-15 de out. 2004. Belém: CESUPA/MPEG, p. 269-281, 2005.

DURKHEIM, Émille. As formas elementares da vida religiosa: o sistema totêmico na Austrália. São Paulo: Paulinas, 1989.

FIGUEIREDO, Arthur Napoleão. As coleções etnográficas da Universidade Federal do Pará. Catálogo. Belém: DEAN/UFPA, 1981 (mimeo).

GEERTZ, Clifford. A religião como sistema cultural. In: . A interpretação das

Culturas. Rio de Janeiro: Zahar, 1978. p. 65-91. 1998.

O saber local: novos ensaios de Antropologia Interpretativa. Petrópolis: Vozes,

HALBWACHS, Maurice. A memória coletiva. São Paulo: Centauro, 2006.

HARTMANN, Teka. Cultura Material e Etnohistória. Revista do Museu Paulista, São Paulo, n. 23, p. 179-197. 1976.

HORNBOSTEL, Erich M. Von; SACHS, Curt. Classification of musical instruments. Galpin society Journal, v. 14, p. 3-29. 1961.

KOCH-GRÜNBERG, Theodor. Dois anos entre os indígenas: viagens ao noroeste do Brasil (1903-1905). Manaus: EDUA/FSDB, 2005. 
LACERDA LIMA, Maria do Socorro. Os Yudjá/Juruna e a conquista portuguesa: um estudo etnohistórico a partir de testemunhos. Relatório Final de Iniciação Científica/UFPA. Belém do Pará: UFPA, 2003.

LARAIA, Roque de Barros. Tupi: índios do Brasil atual. São Paulo: FFLCH/USP, 1986.

LARAIA, Roque de Barros; DAMATTA, Roberto. Índios e Castanheiros: a empresa extrativista e os índios no médio Tocantins. Rio de Janeiro: Paz e Terra, 1978.

LERY, Jean. Viagem à terra do Brasil. São Paulo: Livraria Martins, 1941 [1576].

MALINOWSKI, Bronislaw. Um diário no sentido estrito do termo. Rio de Janeiro: Record, 1997.

MASTOP-LIMA, Luiza de Nazaré. O tempo antigo entre os Suruí Aikewára: um estudo sobre mito e identidade étnica. 2002. 140 f. Dissertação (Mestrado em Antropologia) - PPGCS, UFPA, Belém do Pará, PA, [2002].

MATTA DA SILVA, Gilmar. Sapurahái de Karuára: mitos, instrumentos musicais e canto entre os Suruí Aikewára. 2007. 107 f. Dissertação (Mestrado em Ciências Sociais/ Antropologia) - PPGCS, UFPA, Belém do Pará, PA, [2007].

MELlO, Maria Ignes Cruz. Música e Mito entre os Wauja do Alto Xingu. 1999. 214 f. Dissertação (Mestrado em Antropologia) - PPGAS, UFSC, Florianópolis, SC, [1999].

MENEZES BASTOS, Rafael José. A musicológica Kamayurá: para uma antropologia da comunicação no Alto Xingu. Brasília: FUNAI, 1978.

MENEZES BASTOS, Rafael José; PIEDADE, Acácio Tadeu de Camargo. Sopros da Amazônia: sobre as músicas das sociedades tupi-guarani. Mana, Rio de Janeiro, v. 5, n. 2, p. 125-143, 1999. Disponível em: http://www.scielo.br/pdf/mana/v5n2/v5n2a05.pdf. Acesso em: 22 mai. 2005.

METRAUX, Alfred. A religião dos Tupinambás. São Paulo: Ed. Nacional/Ed. da USP, 1979.

MONTARDO, Deise Lucy. Através do Mbaraka: Música e Xamanismo Guarani. 2002. 276 f. Tese (Doutorado em Antropologia Social) - PPGAS, USP, São Paulo, SP, [2002].

Através do Mbaraka: Música e Xamanismo Guarani. São Paulo: EDUSP, 2009.

POMIAN, Krzysztof. Coleção. Enciclopédia Einaudi - Memória/História. v. 1. Porto: Imprensa Nacional/Casa da Moeda, 1985. p. 51-86.

RIBEIRO, Berta. Geysa. Dicionário do Artesanato Indígena. Belo Horizonte/São Paulo: Itatiaia/EDUSP, 1988. 
RIBEIRO, Berta. Geysa; VELTHEM, Lúcia Hussak Van. Coleções Etnográficas: documentos materiais para história indígena e a etnologia. In: CARNEIRO DA CUNHA, Manuela (Org.). História dos Índios do Brasil. São Paulo: Companhia das Letras/Secretaria Municipal de Cultura/FAPESP, 1992. p. 311-338.

RIBEIRO, Darcy. Os índios urubus ciclo anual das atividades de subsistência de uma tribo da floresta tropical. In: . Uirá sai à procura de Deus: ensaios de etnologia e indigenismo. Rio de Janeiro: Paz e Terra, 1980. p. 31-59.

Diários Índios: Os Urbus-Kaapor. São Paulo: Companhia das Letras, 2008.

SEEGER, Anthony. Os velhos nas sociedades tribais. In: . Os índios e nós: estudos sobre sociedades tribais brasileiras. Rio de Janeiro: Campus, 1980. p. 61-79

Novos horizontes para a classificação dos instrumentos musicais. In: RIBEIRO, Darcy et al (Org.). Suma Etnológica Brasileira: v. 3 - Arte índia. Petrópolis: Vozes/FINEP, 1987. p. 173-179.

STADEN, Hans. Duas Viagens ao Brasil. São Paulo/Belo Horizonte: EDUSP/Itatiaia, 1988 [1557].

TEIXEIRA PINTO, Márnio. Ieipari: sacrifício e vida social entre os índios Arara (caribe). São Paulo: Hucitec, 1997.

VELTHEM, Lúcia Hussak Van. O objeto etnográfico é irredutível?: Pistas sobre novos sentidos e análises. Boletim do Museu Paraense Emílio Goeldi, Belém, v. 7, n. 1, p. 5166, 2012.

VIDAL, Lux. Morte e vida de uma sociedade indígena brasileira: os Kayapó-Xikrin do rio Cateté. São Paulo: HUCITEC/EDUSP, 1977.

VIDAL, Lux; LOPES DA SILVA, Aracy. O sistema de objetos nas sociedades indígenas: arte e cultura material. In: LOPES DA SILVA, Aracy; GRUPIONI, Luís Donisete Benzi (Org.). A temática indígena na escola: novos subsídios para professores de $1^{\circ}$ e $2^{\circ}$ graus. Brasília: MEC/MARI/UNESCO, 1995. p. 370-402.

VIVEIROS DE CASTRO, Eduardo. Araweté: os deuses canibais. Rio de Janeiro: Zahar, 1986.

Recebido em: 14/07/2015 * Aprovado em: 08/12/2015 * Publicado em: 31/12/2015 